\title{
Teachers' Attitudes as a Factor in the Realization Inclusive Education Practice in Primary Schools in Nyeri Central District
}

\author{
Margaret Nyambura Wagithunu
}

\author{
School of Education, Mount Kenya University \\ Email: nwagithunu@gmail.com
}

\author{
Doi:10.5901/mjss.2014.v5n5p
}

\begin{abstract}
In spite of the enormous efforts put forth by families, special educators, and mental health professionals, the individual with a learning disability has one final challenge to meet in life: social acceptance (Frengut, 2003). Today, a child with disability must be capable of gaining acceptance into a societal structure that can be cruel and rejecting at times. By definition, the person with disability already feels marginalized from mainstream society, and entry into the world community places a tremendous burden on their shoulders. As was the case in the United States before the enactment of the Education for all Handicapped Children Act (1975), (Ryndak \& Alper, 1996), it is very likely that majority of children with disabilities do not receive any educational services in Kenya. These are the children and youth most likely to be denied access to the schools as they are deemed unlikely to benefit from any education or be hidden away by their parents (Dorothy, 2003). Even though parents may recognize education as a right for every child and rise above society's negative attitudes, they cannot require that schools open their gates to all children. Schools can still decide that some children are 'uneducable' and therefore do not belong in the school environment. There are bound to be challenges that schools face in the effort to fully embrace the notion of inclusive education.
\end{abstract}

Keywords: Education, Inclusive, Leaners, Special Needs,

\section{Background to the Study}

Children with disabilities have existed in all societies for a long time without their problems being paid attention to. The community see them like people who have little or nothing to contribute to the welfare of the society (Olson, 2003). United Nations Educational Scientific and Cultural Organization (UNESCO, 1974), expressed the views that parents of the handicapped children tended to feel ashamed of such children and therefore treatment they received was indifferent.

Historically, societies have responded in various ways towards persons with disabilities (Campbell, Gilmore \& Cuskelly, 2003). Payne and Mercer (1975) and Payne and Thomas (1978) stated that the treatment of persons with disabilities has been through four historical eras:

$1^{\text {st }}$ phase - Extermination: During this era, the Greeks and the Romans killed newly born infants who were found to have physical deformities and severe form of mental retardation.

$2^{\text {nd }}$ phase - Ridicule: The physically handicapped and the mentally retarded were made court clowns and were used to entertain the privileged class.

$3^{\text {rd }}$ phase - Social conscience: During the middle ages instead of ridiculing them, the church decided to put the disabled in asylums and accorded them humane and charitable care.

$4^{\text {th }}$ phase -Era of education and vocational adequacy: This period, which stretches to the present, perceive the disabled as capable of benefiting from education; vocational training, self-reliance and other societal norms.

Treatment of persons with disabilities in Africa and other developing countries is not well documented. Some communities regarded exceptional individual as being cursed by gods, ancestral spirits or other animistic or magical forces. Retardation was thus seen within such context as a phenomena beyond the scope of ordinary mortals and therefore to reach atonement sacrificial offerings to the gods, ancestral spirits, magical and related curative measures were more often than not resorted to. However most African communities accepted the handicapped; they were not excluded from the ritual life of the community or from the education given by parents, older siblings and extended family. They were taken as equal parties in the life of the community and the traditional education.

Muchiri (1982) reviewed literature which showed in East Africa, persons with disabilities were perceived as incapable of engaging in gainful employment. Practice of viewing persons with disabilities as incapable of gainful employment is embedded in the original Kiswahili term "wasiojiweza" which means those incapable of performing. Additionally "kiwete" the swahili word for the physically disabled denotes the meaning of an object not a person. Hewett 
and Forness (1984), argue that, as science provided more and more information about the natural causes and bases of disability, explanations based on unnatural causes lost force. Survival thus became less of an issue than did the questions of proper treatment through the provision of services to persons with disabilities.

In a highly competitive world, where success is judged by ones educational achievement and economic status, the children with disabilities have to learn not only to accept the limitations placed upon them by their handicap but also how to measure up to all the demands which society places upon him or her. Theme of the international year of the disabled person, 1981, stated "Full participation of disabled persons." This theme was developed from an international meeting held at UNESCO headquarters, Paris in October 1979 which had emphasized the need for a commitment by all Governments and individuals to integrate the disabled as fully as possible into their societies. More recent international involvement in the area of disability was seen at the $17^{\text {th }}$ world congress of Rehabilitation International held in Nairobi, Kenya in September 1992. This meeting stressed the urgent need for total integration of the disabled in the society each according to his or her own ability.

Kenya supports this by having assessment centers and resource centre which assess children with various disabilities in order to have them referred to appropriate schools where they are able to pursue educational goals with least problems. We have special schools which have been established as well as special units within regular schools to cater for the educational needs of the persons with disabilities. It is important for every society to realize that persons with disabilities are also part of that society they belong to. It is therefore the responsibility of the society to ensure that its persons with disabilities become fully integrated in the society and become economically independent. Experts in special education argue that full integration for persons with disabilities can only be achieved if schools accept to offer training in the same environment for all children regardless of their physical, mental, or social status, or what is referred to as inclusive education.

Inclusive education is rooted in the right to education as enshrined in Article 26 of the 1948 Universal Declaration of Human Rights. A number of treaties and normative instruments have since reaffirmed this right, three of which are mentioned here. UNESCO's 1960 Convention against Discrimination in Education stipulates that States have the obligation to expand educational opportunities for all who remain deprived of primary education. The 1966 International Covenant on Economic, Social and Cultural Rights reaffirms the right to education for all and highlights the principle of free compulsory education. Finally, the Convention on the Rights of the Child, the most widely ratified human rights treaty, spells out the right of children not to be discriminated against. It also expresses commitments about the aims of education, recognizing that the learner is at the centre of the learning experience. This affects content and pedagogy, and - more broadly - how schools are managed (Govinda, 2009).

According to UNESCO (1994) inclusion has become the most effective approach to address the learning needs of all students in regular schools and classrooms. International initiatives from the United Nations, UNESCO, the World Bank and Non-governmental organizations jointly contribute to a growing consensus that all children have the right to be educated together, regardless of their disability or learning difficulty and that inclusive education is a human right that makes good educational and social sense. The current thinking advocates educating the persons with disability within the regular school community, rather than segregating them in special schools except the very severe to profound handicapping conditions. They have a right to lead dignified lives and should be given every opportunity to compete on equal terms with non-disabled children. It is however not clear whether teachers in Kenya have developed positive attitudes towards inclusive education, and the factors influencing such attitudes.

Historically, teachers have not been favorably disposed to the policy of increased inclusion of children with special needs within the regular classroom (Campbell, Gilmore \& Cuskelly, 2003). Their concerns include the amount of individualized time children with special needs might require, possibly to the detriment of other students; apprehension as to the quality of work produced by children with special needs; lack of adequate support services; and teachers' concerns about deficiencies in their own training and preparation in the skills required to support inclusive educational practice (Tait \& Purdie, 2000). It is however not clear the factors that influence teachers' attitudes toward inclusion in Kenya.

\section{Methodology}

The study adopted an exploratory approach using a descriptive survey design to investigate the factors influencing teachers' attitudes toward inclusive education in primary schools in Nyeri Central district. Descriptive survey designs were used in preliminary and exploratory studies(Luck and Ruben, 1992) to allow researchers to gather information, summarize, present and interpret for the purpose of clarification (Orodho, 2002). Descriptive survey research is intended to produce statistical information about aspects of education that interest policy makers and educators (Borg and Gall, 1989). The choice of this design is made based on the fact that the researcher did not manipulate variables. Descriptive 
and analytical statistics were used to analyze the data obtained. Data collected from the field was coded and entered into the computer for analysis using the Statistical Package for Social Sciences (SPSS).

\section{Theoretical Reviews}

\subsection{Rosenberg's Theory of Affective-Cognitive Consistency}

Rosenberg (1960) concerned himself primarily with conceptualising what happens within the individual when attitudes change. He was particularly interested in the relation between affective and cognitive components of an attitude change. Rosenberg linked cognitions about the attitudes object with the person's values. Strong positive affect toward an attitude object should be associated with beliefs that it leads to the achievement of important values, and negative affect toward an object, suggests that it blocks the attainment of these values.

He postulated that if either affect or cognition shifts markedly, inconsistency arises and produces a force toward changing the remaining component. Other researchers agree with Rosenberg. For example Eagly and Chaiken (1973) and Triandis (1971) viewed cognitive component as containing the ideas, thoughts, or beliefs which are used by people in thinking. They said that these ideas or thoughts are inferred from consistencies in responses to discriminably different stimuli. The effective component of attitude consists of feelings, moods and emotions that people experience in relation to the attitude object (Eagly and Chaiken, 1993). These affective responses could range from extremely positive to extremely negative attitude and hence considered as evaluative responses.

\subsection{Kelman's Three-Process Theory of Attitude Change}

Kelman's (1961) Three-Process Theory of Attitude Change argues that there are three distinct processes of social influence thus compliance, identification and internalisation. Compliance occurs when a person accepts influence from another individual or a group because he expects to obtain favourable reaction from the other. With this process private attitudes are likely to occur only when it may be observed by the influencing agent. Identification occurs when a person adopts certain actions or attitudes because they are associated with a satisfying self-defining relation to another individual or group. These actions may closely resemble the behaviour of the other person, or they may be based on a relation to him that demand quite different behaviour. The continuance of the actions or attitudes depends upon maintaining a continued relation to the influencing agent.

Internalisation according to Kelman (1961) is the third process and occurs when a person accepts influence because the induced behaviour is congruent with his value system. In this case, but not in the cases of compliance of identification, the attitude or behaviour is intrinsically rewarding. The theory takes into account the source of power of the influencing agent, the various conditions that control each of the influence processes, and their implications for permanence of attitude change. Thus an individual with a positive attitude towards inclusive education system would support the government because one of the values to which he subscribes is that government should provide education for all its human population.

Of these various processes the one likely to occur depends in part upon the source of the influencing agent when the influencing agent is in a position to closely observe an action or a statement of opinion, compliance is likely to occur. The child behaves well when the stern parent is watching him. Identification requires that the influencing agent be a salient one, the relation must dominate the situation. Therefore people who evaluate an attitude object favourably may show positive regard to the attitude object. On the other hand people who evaluate an attitude object unfavourably show behaviours that hinder or oppose it, this shows that attitude guides behaviour.

Kelman (1961) finally postulated that attitudes or action that have been internalised are likely to be expressed only when the values that were relevant to the initial acquisition are activated. A final point of importance is that particular situations are not necessarily pure examples of just one of these processes. Often two or more processes occur simultaneously or all three may operate together. Thus, if an agent has powerful control over a person but the relation is also a satisfying one, both compliance and identification are likely to occur. In addition, if the attitudes or actions required by this situation are also congruent with other attitudes held, internalisation may take place. 


\section{Literature Review}

\subsection{The Concept of Inclusion}

Inclusive education is rooted in the right to education as enshrined in Article 26 of the 1948 Universal Declaration of Human Rights. A number of treaties and normative instruments have since reaffirmed this right, three of which are mentioned here. UNESCO's 1960 Convention against Discrimination in Education stipulates that States have the obligation to expand educational opportunities for all who remain deprived of primary education. The 1966 International Covenant on Economic, Social and Cultural Rights reaffirms the right to education for all and highlights the principle of free compulsory education. Finally, the Convention on the Rights of the Child, the most widely ratified human rights treaty, spells out the right of children not to be discriminated against. It also expresses commitments about the aims of education, recognizing that the learner is at the centre of the learning experience. This affects context and pedagogy, and more broadly, how schools are managed (Govinda, 2009).

However, the right to education does not automatically imply inclusion. The right to inclusive education was initially stated in the Salamanca Statement and Framework for Action on Special Education in 1994 which emphasized that the schools need to change and adapt to the diverse needs of all learners (UNESCO, 1994). The UN Convention on the Rights of Persons with Disabilities established inclusive education as a legal right. The importance of proper resourcing for inclusion is also highlighted in the Standard Rules on the Equalization of Opportunities for Persons with Disabilities and other disability movement documents. There is however still a long way to go before Education for All becomes a reality and it will not work unless there are more participation at all levels, change of attitudes, allocation of resources and alleviation of poverty among others (Mwaura, 2009).

A conference held in Spain, where more than 300 participants representing 92 governments and 25 International Organizations furthered the objective of education for all by considering the fundamental policy shifts required to promote the approach of inclusive education. The conference adopted the Salamanca Statement and Framework for Action that asserted that, "schools should accommodate all children regardless of their physical, intellectual, social, emotional, linguistic or other conditions. Among the groups of children that should be included in schools were those with disabilities, children from nomadic populations, children from linguistic, ethnic or cultural minorities, children living under especially difficult circumstances, for example, street children and those from other disadvantaged or marginalised areas or groups among others (UNESCO, 1994).

The statement reaffirmed the right to education of every individual as enriched in the 1948 universal declaration of human rights, and reviewing the pledge made by the world community at the 1990 world conference on education for all to ensure the rights for all regardless of individual differences. The conference recalled several United Nations declarations culminating in 1993 United Nations standard Rules on the Equalisation of opportunities for persons with disabilities which urges states all over the world to ensure that the education of person with disabilities is an integral part of the educational system. Finally they noted the increased involvement of governments, advocacy groups, community and parent groups and in particular organizations of persons with disabilities in seeking to improve access to education for the majority of those with special needs still unreached (UNESCO, 1994).

From this document many governments and schools face serious inclussionary pressures from Human Rights Organization (e.g. the United Nations) and other advocates of inclusive education (Hall, 1992) Salamanca recommendations emphasized the fundamental right to education for every child, unique characteristics, interests, abilities and learning needs, the need to structure educational systems and design the programmes to accommodate them within a child centred pedagogy capable of meeting these needs. The conclusion arrived here was that regular schools with this inclusive orientation are the most effective means of combating discriminatory attitudes, creating welcoming communities building an inclusive society and achieving education for all. Moreover, they provide an effective education to the majority of children and improve efficiency and the cost effectiveness of the entire education system (Salamanca Statement UNESCO, 1994).Ainscow (1990) observed that although inclusion is a common word, its discourses have had multiple meanings which are used in a way that masks the attitude of people in the social structure of life. Slec (1995) adds that inclusion is listening to all voices and learning with one another to experience a society based on non-discriminative acts by practicing social justice. According to Kauffman (1995) the philosophy of inclusive education is focused on educating all learners in the same classroom. And, that each student's unique educational needs be met through adaptation of equipment specialized instruction and personnel. Inclusive education therefore involves all children learning together with the peers in the same physical environment thus extending the scope of the schools so that it can include a greater diversity of children. The argument here is that society is an inclusive community with people of varying abilities/disabilities, race language, etc. As such prepare children for this kind of life. 


\subsection{Inclusive Education versus Integrated Education}

Inclusion follows from integration (mainstreaming) but differs from it in that in integration, the child must make adjustments to the requirements of the school but in inclusion it is the school that must make adjustments to accommodate or include the child (Waruguru, 2002). Waruguru (2002) argues that integrated education views the child as the problem while inclusive education looks at the education system as the problem, as illustrated in Figure 2.1 and Figure 2.2.

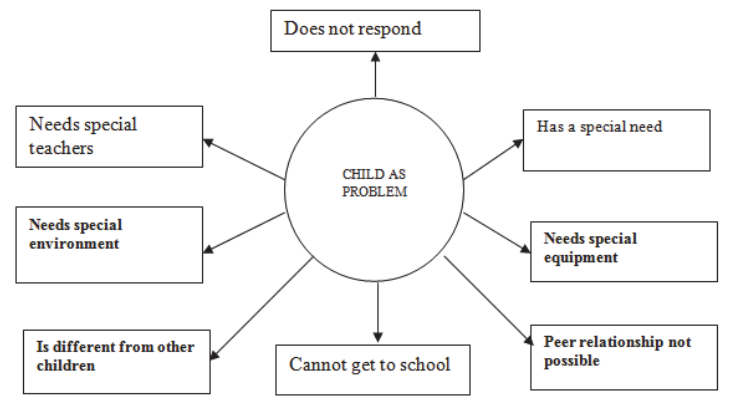

Figure 2.I: Integrated Education: Child as the ProblemSource: Waruguru, M. (2002). Inclusive Education Module One, Nairobi: Kenya Institute of Special Education, KISE.

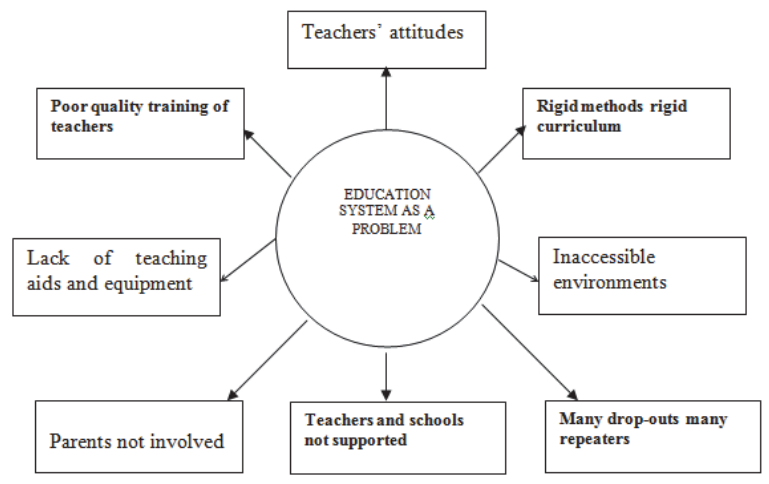

Figure 2.2: Inclusive Education: Education System as the Problem Source: Waruguru, M. (2002). Inclusive Education Module One, Nairobi: Kenya Institute of Special Education, KISE.

There is a shift from the child to the environment, what the environment (school) can do for the child with educational needs. For Ainscow (1995), integration means going to school (as visitor), while inclusion means participation in school life. The goal of inclusion is not to erase differences but to enable all pupils to belong within an educational community that validates and values their individuality (Knight, 1999).

For Giorcelli (1995), full inclusion involves age and grade appropriate placements in neighbourhood schools, zero rejection philosophy, co-operative beaming and special educational support given to regular education. Savolainen et al. (1998) observed inclusive education as evolving from a movement associated with the struggle against exclusion of learners with disabilities and others categorized as having special needs, to one which challenges all exclusionally policies and practices in education, thus it is an approach which aims at removing any barriers to learning.

Inclusive education involves a different vision of regular education, a vision based in heterogeneity instead of homogeneity (Soder, 1997). It is the only way to right education to equal opportunities and participation. It is not just about the access of some given groups of students traditionally excluded but to transform the educational system as a whole in order to attend the diversity of educational needs of all children (Stangvik, 1997).

Inclusive education caters not only for educational needs, but is also solid social and moral arguments for it. It can 
lay the foundations of a more inclusive society where all people belong and where being different is accepted and valued as just part of humanity (Inclusive International, 1995). The philosophy of inclusive education is focused on educating all learners in the same classroom, and, that each student's unique educational needs be met through adaptation of equipment, specialized instruction and personnel (Kauffman, 1995). Inclusion should utilize natural proportions where student's disability is not used as a factor to suggest placement observed (Hegarty, 1997). This philosophy came after the previous philosophies on integration, mainstreaming and normalization. According to Stainback and Stainback (1992) all children should be included in educational and social life of the neighbourhood school. And that inclusive education should build a system of education that meets everyone's needs.

\subsection{Some Studies done on Inclusive Education outside Africa}

In the United States of America the idea of including students with disabilities in regular schools with support services was first envisioned in 1970's (Stainback and Stainback, 1989). This evolved from a long series of legislative and political events that emphasized equal participation of students with disabilities. In 1986, the United States Department of Education called for full inclusion for all students with disabilities; later research on inclusion began to show benefits such as availability of age-appropriate role models (Ainscow, 1994). Today it could be said that USA has led in implementing inclusive schooling, approximately $71 \%$ of learners with disabilities are educated in regular classes (Ainscow, 1999). It could be argued that in such schools, diversity and disability heterogeneity has been seen as a positive element in fostering appreciation of individual differences.

In Canadian states, laws have been developed pertaining to education for children with disability, (Aefksy, 1995). However, the Charter of Rights, and Freedoms (1982) states that each citizen has a right to equal benefit without discrimination. In this context, Canadian states developed laws pertaining to education for children with disabilities Aefsky (1995).

Wilezenski (1992) cited in Booth and Ainscow (1998), conducted a study in Australia on teacher attitudes towards inclusive education. He found that teachers were more positive about students whose programmes focused on social inclusion than those requiring physical changes in their school or classroom. The teachers were also more accepting to students with physical disabilities than to those who necessitated academic modifications. Such research findings indicate that the type of disability and the demands it eventually makes on the teacher will influence teacher attitudes towards including a child with such a disability in a regular class. A study done by Peresuh and Ndawi (2001) in Canada argued that countries of the south lack financial, human and material resources to effectively provide educational and related services to learners with visual and hearing impairments.

\subsection{Studies Done on Inclusive Education in Africa}

Studies done in South Africa by Savaloinen et al (1996) found that Constitution of South Africa points out clearly that everyone has the right to basic education. This means that all children whatever their needs and differences have the right to equal educational provision. The South African School Act 1996 also asserts the right of equal access to basic and quality education for all learners without discriminating in any way. No learner may therefore be denied admission to any ordinary school on any ground, including disability, language, difficult in learning and other impairments, where it is reasonably practicable, which is the first step towards a single inclusive education system in South Africa.

In Zambia Savolainen et al (1996) show that 40\% of school age children do not attend school. The reasons for this are educational costs, distance to and from school, declining health conditions such as HIVIAIDS infections which lead to an increased numbers of orphans, poverty and inadequate educational opportunities. It is estimated that only $2 \%$ of school-aged children with special education needs attend school. However since 1990 there has been an improvement in teacher training where a special component is offered this is in line with the idea of inclusive schooling. Most children with special needs study mostly in ordinary classes with special education teachers assisting the class teachers in their work.

According to Mushoriwa (1998) research findings suggest that while the blind child may be included physically, he/she may remain socially and academically excluded because of attitudes of teachers (and perhaps pupils). In the end these children do not live an independent life as adults and certainly this would indicate that they pursued an education system from which they did not benefit. Many of the teachers interviewed felt that these children should be in special schools.

Most studies done in Kenya have recommended integration philosophy of education provision for children with various disabilities. Mwangiri (1989) found that integration of hearing impaired children in its various forms was not only possible but that it should be pursued more. He further recommended that more teachers be trained to support and guide 
the teachers in ordinary schools. This has been realised with launching of Distance Education programme at Kenya Institute of Special Education (KISE) which is currently training learners from all over Kenya as a parallel programme to a full time programme that is training diploma teachers in special education.

Mwaura (2001) conducted a study of teachers' attitudes on teaching the hearing impaired children together with the hearing. He found that there was a general consensus among all the teachers who participated in the study that children with hearing impairments should be educated just like their hearing brothers and sisters. However, he postulated that attitudes could be the greatest barrier or the greatest asset to the development of integrated schools. They may influence the challenges to be chosen and goals to be achieved if education for all is to be achieved, it has to start with a change of attitudes (Mwaura, 2001).

Ainscow (1999) found that while some African countries are still practicing the old tradition where children with special needs were categorized and placed in special schools, the trend has been changing with inclusive education being advocated globally. However, the impact of inclusive in African countries is yet to be felt according to Hegarty (1997) in theory many countries have shown the interest. In Karugu's 2001 survey of the status of inclusion in Kenya about $80 \%$ of educators indicated they would like to learn more about inclusive education.

\subsection{Studies of Teacher Attitudes towards Inclusion}

Favourable teacher attitudes are thought by many educators to be crucial if inclusive education will succeed. Booth and Ainscow (1998) contend that in studies involving inclusive education, it is absolutely imperative for the investigator to specify the type of special needs because teacher attitudes have been found to vary with the type of disability and the extent of instructional adaptations required for accommodating such students.

Rajecki (1982) argues that attitudes are such an important area to study because they influence so much of our personal lives. To him, attitudes include desires, convictions, feelings views, opinions, beliefs, hopes, judgments and sentiments. The study of attitudes is thus important because there is a general belief that human behaviour and actions are influenced by attitudes, whereby attitudes are seen as the cause and behaviour as the consequence (Mushoriwa 1998).

Cava and Madison (1978), suggested that unfavourable teacher attitudes towards accepting handicapped children stem from insecurity and sometimes sentiment, arising from ignorance and inexperience of handicapped children. According to these writers what seems to be important in influencing teachers' attitudes is their knowledge of the implications of handicap and their experience of children with a particular handicap. Many studies have revealed that a handicapped child's position on the teachers' desirability scale had a direct relationship to the teachers' knowledge of that handicap. Among the lowest ranked groups on the desirability scale were children with hearing impairments and visual impairments (Murphy, Dickstein and Dripps, 1960). That teachers need knowledge and understanding of handicap if they are to feel competent to teach a handicapped pupil and to receive him willingly into their classes accord very much with common-sense-reasoning, so also does the idea that experience with a pupil helps teachers feel more confident in having such a child in their class (Lunas, 1986).

In addition to knowledge and experience there are two other major factors which have been demonstrated to be important in fostering positive attitudes among class teachers towards handicapped pupils, these are an ideological commitment to the principal of integrating handicapped children into normal society and the provision of adequate resources and support services to help the teacher cope with the additional responsibility of a handicapped child.

With regard to the issue of ideological commitment, the research findings from Schultz (1982) suggest that a belief that handicapped children should be educated in ordinary schools is a significant independent factor in promoting positive attitudes in teachers towards handicapped pupils. Likewise, the provision of special facilities and extra resources for class teachers receiving handicapped children into their classes has been shown to be important by several investigators for example, Schultz (1982). He emphasized that class teachers as well as being given information and advice, should receive additional help such as the services of a classroom or welfare assistance or specialist support teacher. Again, it seems to accord with common-sense reasoning that teachers given extra assistance will feel more favourable to the presence of a handicapped child in the class and more confident in their ability to serve his/her often very time-consuming special needs. A conclusion that can thus perhaps be safely reached from the literature reviewed above is that ordinary class teachers are more likely to have positive attitudes towards a handicapped pupil if they belief they can make a contribution towards his/her educational development. 


\section{Presentation and Discussion of the Findings}

\subsection{Demographic information of the respondents}

The demographic information of the 80 teachers in the sample is very important to this study. Teachers are the key implementers of the curriculum and as such this information will enable the researcher to draw conclusions on the teachers who are already in the field. This information will enable the researcher to know to which extent teachers have been involved in implementing inclusive education practices, skill and knowledge, their interest and attitude toward working with students with diverse needs. Table 4.1 below illustrates demographic information of all teachers who participated in the study. The following is the summary of their background information; that is teachers' gender, type of schools they teach( regular or regular with special), teaching experience (length of service in years), current position which will indicate whether one is a trained special teacher or not a trained special teacher and whether the teacher has ever encountered persons living with disabilities.

Table 4.1: Demographic information of the teachers

\begin{tabular}{llcc}
\hline & Background variables & Frequency & Percentage \\
\hline \multirow{3}{*}{ Gender } & Male & 35 & 43.8 \\
& Female & 45 & 56.2 \\
& Total & 80 & 100.0 \\
\hline \multirow{3}{*}{ Type of school } & Regular & 51 & 63.8 \\
& Regular with special & 29 & 36.2 \\
& Total & 80 & 100.0 \\
\hline \multirow{3}{*}{ Teaching experience(length of } & $1-5$ & 10 & 12.5 \\
service in years) & $6-10$ & 10 & 12.5 \\
& $11-15$ & 14 & 17.5 \\
& 16 and above & 46 & 57.5 \\
& Total & 80 & 100.0 \\
\hline \multirow{3}{*}{ Current position } & Trained special teacher & 38 & 47.5 \\
& Not trained special teacher & 42 & 52.5 \\
& Total & 80 & 100.0 \\
\hline \multirow{2}{*}{ Encountered person with disability } & Yes & 37 & 46.2 \\
& No & 43 & 53.8 \\
& Total & 80 & 100.0 \\
\hline
\end{tabular}

\subsection{Gender}

The participants comprised 80 teachers from public primary schools in Nyeri-Central district. Out of 80 teachers, there were 35 (43.8\%) males while 45 (56.2\%) were females. This indicates that in Nyeri- Central district where the study was carried out most public primary schools were taught by female teachers and only few had male teachers. The district being the headquarter of both Central province and Nyeri District the spouses of the public officers working in those offices who happen to be teachers are posted to the nearby school within town that is Nyeri- Central District. For this reason, female teachers are bound to be more than male teachers in the schools.

\subsection{Type of school}

As shown in the table 4.1, teachers who reported to teach in regular schools (without a special unit) were 51 (63.8\%) while those who indicated they taught in regular schools with a special unit were $29(36.2 \%)$. This indicates that most of the teachers in Nyeri-Central district teach only 'normal' pupils in regular schools. As a result the teachers tend to be content specialists and more likely to focus on teaching the content than on individualizing instruction to meet the unique needs of each student. On the other hand the few teachers who teach in school with special need may end up with very large classes of learners with varying disabilities making teaching difficult. This implies that only few teachers are available and appropriately trained to teach inclusive education in Nyeri- Central District. 


\subsection{Teaching experience}

The above table shows that $10(12.5 \%)$ teachers reported that their length of service in teaching was between 1 and 5 years, $10(12.5 \%)$ indicated $6-10$ years,14(17.5\%) teachers reported they had taught for 11-15 years while the remaining $46(57.5 \%)$ teachers indicated they had experience of 16 years and above. This may be as a result of stagnation of employment of teachers by the teachers' service commission (TSC) in the public schools in the last 15 years. The general observation is that majority of the teachers who are in the field currently where the study was carried out are the old teachers who are likely to have no skills toward inclusive education. The current understaffing in school are likely to have contributed to the result findings presented above. The few teachers who are young with 1-10 years of experience are likely to have some knowledge and skills of handling inclusive education but they face challenges in implementing it due to the negative attitude of old teachers who are the majority in the field.

\subsection{Teachers' current positions}

Teachers were asked the positions they held in their various schools, as this may affect their attitudes towards inclusive education. Table 4.1 shows their current positions. It illustrates that 38 (47.5\%) teachers indicated that they are regular teachers with special needs education training while 42 (52.5\%) teachers indicated that they were regular teachers without special needs education training. This implies that some of the teachers with special needs education training in Nyeri-Central district are working in regular schools due to understaffing in the district and are not utilized maximally hence their presence and contribution to inclusive programme is not felt much. Teacher with special need lack appropriate National policy on provision of learning resources to children in inclusive programme hence teachers are not effective to a greater extent and are discouraged. Curriculum barriers affect teachers who are already trained in special needs; they need content that is meaningful to meet needs of every learner in an inclusive setting.

Special needs education training may help teachers in coping better with children with disabilities, since not all schools had special units yet they had children with disabilities. The implication is that children in regular schools did not perform well since besides having no facilities; teachers were also not trained on special needs.

\subsection{Encountered person living with disabilities}

Teachers were further asked whether they had ever encountered a person living with a disability (either a relative or a close friend). Their responses are shown in table 4.2.1.The table shows that $37(46.2 \%)$ teachers indicated that they had an encounter with a person living with disability (relative or a friend) while $43(53.8 \%)$ indicated they had not. This implies that most of the teachers in Nyeri-Central district may have difficulties in understanding pupils with special needs due to lack of close interaction and hence fail to understand diverse needs of each individual's pupils in the classroom. As a result the teacher may fail to vary teaching methods, pace, motivation and appreciation of all pupils.

\subsection{Effects of Training of Teachers in Special Education on their Attitudes toward Inclusive Education}

The first objective of the study was to determine the effects of training of teachers in special education on their attitudes toward inclusive education. Training in any field is very essential for the sake of gaining the knowledge needed to perform the duties one is expected to perform. More so, special education training is important to teachers, since it helps them to be able to teach children of all kinds whom they will encounter in their profession.

\section{Teachers' views on effects of inclusion}

Teachers' views on effects of inclusive education enable the researchers to acquire information on how pupils with disabilities were handled in public primary schools. It reveals the success of the programme, its strength and weaknesses. In addition it helped the researcher to draw conclusions and give recommendations on the programme. Teachers were asked to give their opinions on including children with disabilities in a regular classroom other than in special schools. The following were their responses both positive and negative. Those who agreed that the children with disabilities should be included in regular classrooms gave reasons for their agreement as shown; the child will learn more from his class mates who will be willing to help, normal children are always ready to give assistance to those with disabilities, the child will be assisted by other children in learning, Other children will appreciate living with them, the 
instruction may be useful to the children who may have mild disabilities, the disabled child gets to learn that he/she is more talented than the normal ones and

It increases acceptance among the peers. Those who felt that the children with disabilities should not be included in regular classrooms gave the following reasons; some children may get so much consumed in helping the disabled ones, the disabled pupils will lower the mean score for the class due to poor performance, if one child decides to reject the disabled child his/her peers are likely to do the same and disabled children require an individualized programme which demands extra time and added work to the teacher yet they are not paid special allowances. To address the first research objective, the teachers were given some items on a Likert scale in order to find out their attitudes on children with disabilities. The teachers were required to state their agreement levels on the 5-point Likert scale ranging from strongly agree to strongly disagree. The teachers' responses are shown in table 4.2.

Table 4.2: Inclusive education

STEM: Including children with disabilities in a regular classroom rather than in special school will:

\begin{tabular}{|c|c|c|c|c|c|c|c|c|c|c|c|}
\hline & \multirow{2}{*}{ Statement } & \multicolumn{2}{|c|}{ SA } & \multicolumn{2}{|r|}{ A } & \multicolumn{2}{|c|}{$\mathrm{U}$} & \multicolumn{2}{|c|}{ D } & \multicolumn{2}{|c|}{ SD } \\
\hline & & $\mathbf{F}$ & $\%$ & $\mathbf{F}$ & $\%$ & $\mathbf{F}$ & $\%$ & $\mathbf{F}$ & $\%$ & $\mathbf{F}$ & $\%$ \\
\hline 1. & increase the child's circle of friends. & 29 & 38.7 & 23 & 30.7 & 2 & 2.7 & 11 & 14.7 & 10 & 13.3 \\
\hline 2. & limit the child's level of academic performance & 11 & 14.7 & 14 & 18.7 & 4 & 5.3 & 30 & 40.0 & 16 & 21.3 \\
\hline 3. & make the child less well adjusted socially & 11 & 14.7 & 13 & 17.3 & 5 & 6.7 & 21 & 28.0 & 25 & 33.3 \\
\hline 4. & $\begin{array}{l}\text { ensure that 'normal' children will be happy to play with the children with } \\
\text { disabilities. }\end{array}$ & 14 & 18.7 & 28 & 37.3 & 4 & 5.3 & 19 & 25.3 & 10 & 13.3 \\
\hline 5. & worsen the child's learning problems & 10 & 13.3 & 12 & 16.0 & 3 & 4.0 & 13 & 17.3 & 37 & 49.3 \\
\hline 6. & have a negative effect on the social development of other children & 8 & 10.7 & 16 & 21.3 & 6 & 8.0 & 14 & 18.7 & 31 & 41.3 \\
\hline 7. & $\begin{array}{l}\text { provide more opportunities for the other children benefit from the } \\
\text { specialized instruction of the children with disabilities }\end{array}$ & 44 & 58.7 & 20 & 26.7 & 2 & 2.7 & 9 & 12.0 & 0 & 0.0 \\
\hline 8. & $\begin{array}{l}\text { develop a stronger feeling in the child of confidence in his/her academic } \\
\text { ability }\end{array}$ & 26 & 34.7 & 35 & 46.7 & 4 & 5.3 & 7 & 9.3 & 3 & 4.0 \\
\hline 9. & $\begin{array}{l}\text { Increase the amount of social rejection by the child's peers } \\
\text { ensure that 'normal' children will be more appreciative of children living }\end{array}$ & 28 & 37.3 & 27 & 36.0 & 0 & 0.0 & 14 & 18.7 & 6 & 8.0 \\
\hline 10. & with disabilities. & 20 & 26.7 & 30 & 40.0 & 2 & 2.7 & 12 & 16.0 & 11 & 14.7 \\
\hline
\end{tabular}

Table 4.2 shows that over 35\% of the respondents strongly agreed with the statements that including children with disabilities in a regular classroom rather than in special school will: increase the child's circle of friends, provide more opportunities for the other children benefit from the specialized instruction of the children with disabilities and also increase the amount of social rejection by the child's peers.

Over $35 \%$ of them agreed with the statements that including children with disabilities in a regular classroom rather than in special school will: ensure that 'normal' children will be happy to play with the children with disabilities, develop a stronger feeling in the child of confidence in his/her academic ability and also ensure that 'normal' children will be more appreciative of children living with disabilities. On the other hand, $40 \%$ of the respondents disagreed with the statement that including children with disabilities in a regular classroom rather than in special school will limit the child's level of academic performance. Over $40 \%$ of them strongly disagreed with the statements that including children with disabilities in a regular classroom rather than in special school will: worsen the child's learning problems and also have a negative effect on the social development of other children. The implication of these findings is that most of the teachers seemed to have no problem with including children with disabilities in regular classrooms. They felt that including children with disabilities in normal classrooms would give both the disabled children and the normal children an opportunity to learn with each other as well as to learn from each other.

On the other hand, there are those teachers who disagreed that children with disabilities should be included in a regular classroom other than in special schools. The reasons they gave for disagreeing were: they will not be comfortable with normal children, they need special schools with facilities that link to their needs, so they should not be in normal schools, they would not socialize well with the normal children, some pupils will make fun of him/her by imitating and refusing to help, other kids would view the disabled as abnormal and refuse to play with them, some cannot learn at the same pace with others, so they cannot be included in the regular schools, normal children and the teachers may not be patient with such children, the children with disabilities would not cope with other normal children, the child will not develop confidence because they will compare themselves with other normal children and also the child will be rejected 
because they cannot do some activities like other normal children. The researcher suggests that Ministry of education should create awareness to teachers in Nyeri-Central district on importance of inclusive education programme, this will enable them to change their attitude towards pupils with disabilities. Consequently, normal learners will develop positive attitudes towards learning with disabled pupils. In addition parents and the school community should be sensitized on benefits of inclusive education.

\subsection{Attitudes towards inclusive education}

There are stereotypic attitudes towards inclusion, disabilities and special needs in various cultures. These attitudes may affect how teachers perceive inclusive education and how they treat children with disabilities. Based on the responses of the teachers to the ten items, the overall scores for the ten attitude items were computed as shown in Table 4.2. The highest score possible for the attitude scale was 75 indicating very positive attitudes while the lowest possible score was 15 indicating very negative attitudes. The mid-point of the scale was a value of 45 , whereby scores below 44 denote negative attitudes; scores above 46 indicate positive attitudes while Forty-five indicated neutral attitudes.

Table 4.3: Attitudes towards inclusion of children with disabilities

\begin{tabular}{cccc}
\hline Attitude & Overall scores & No. of teachers & Percent \\
\hline \multirow{3}{*}{ Very negative } & 27 & 2 & 2.5 \\
Negative & 28 & 2 & 2.5 \\
& 29 & 1 & 1.3 \\
& 30 & 3 & 3.8 \\
& 32 & 5 & 6.3 \\
Neutral & 36 & 1 & 1.3 \\
& 38 & 1 & 1.3 \\
Positive & 40 & 1 & 1.3 \\
& 41 & 1 & 1.3 \\
& 43 & 3 & 3.8 \\
& 44 & 6 & 7.5 \\
& 45 & 8 & 10.0 \\
& 46 & 6 & 7.5 \\
& 47 & 9 & 11.3 \\
& 48 & 1 & 1.3 \\
& 50 & 2 & 2.5 \\
& 52 & 2 & 2.5 \\
& 53 & 2 & 2.5 \\
& 54 & 9 & 11.3 \\
& 55 & 5 & 6.3 \\
& 56 & 2 & 2.5 \\
& 58 & 1 & 1.3 \\
& 59 & 2 & 2.5 \\
& 65 & 3 & 3.8 \\
& 56 & 2 & 2.5 \\
& & 80 & 100.0 \\
\hline
\end{tabular}

Table 4.3 shows that $5(6.3 \%)$ of the teachers had very negative attitudes, $21(26.3 \%)$ had negative attitudes, $8(10 \%)$ were neutral, $41(51.3 \%)$ had positive attitudes while $5(6.3 \%)$ had very positive attitudes. The teachers seemed to have a positive attitude towards inclusion, implying that they were ready to teach both children with disabilities and normal children in one class. This may be due to the fact that they were trained in handling children with disabilities, and also because they felt including children with disabilities in normal classes would be of benefit to the children with disabilities.

\subsection{Differences in attitude among teachers trained in special education and those not trained in Special education towards inclusive education}

In order to establish this, the mean scores of teachers trained in special education and those not trained in special education were computed and their results compared. Table 4.4 shows the mean scores obtained by the teachers across their attitudes towards inclusive education. 
Table 4.4: Training in special education versus attitudes towards inclusive education

\begin{tabular}{lccc}
\hline & N & Mean & Std. Deviation \\
\hline Regular teacher with special needs education training & 38 & 37.68 & 4.275 \\
Regular teacher without special needs education training & 42 & 33.98 & 6.178 \\
Total & $\mathbf{8 0}$ & $\mathbf{3 5 . 7 4}$ & $\mathbf{5 . 6 4 3}$ \\
\hline
\end{tabular}

The information in table 4.4 suggests that regular teachers with special needs education training seemed to have more positive attitudes compared to regular teachers without special needs education training. T-test was used to test the first hypothesis of the study which stated:

Ho1: Training of teachers in special education has no significant impact on their attitudes toward inclusive education. To test this hypothesis, a t-test was used to determine whether teachers trained in special education and those who were not trained differed significantly in their attitudes toward inclusive education. The results of the analysis are shown in table 4.5 .

Table 4.5: T-test statistics for training in special education versus attitudes towards inclusive education

\begin{tabular}{lccccc}
\hline & $\mathbf{t}$ & $\mathbf{d f}$ & Sig. (2-tailed) & Mean Difference & Std. Error Difference \\
\hline Equal variances assumed & 3.090 & 78 & $.003^{*}$ & 3.71 & 1.200 \\
Equal variances not assumed & 3.145 & 73.170 & .002 & 3.71 & 1.179 \\
*Significant at $p<0.05$ & \multicolumn{5}{l}{}
\end{tabular}

As shown in Table 4.5, the t-test revealed that there was a significant effect of training on attitudes towards inclusive education at $p<0.05$ level of significance. As indicated in Table 4.4 teachers who were trained in special education had higher mean scores on the attitude scale than those not trained in special education. This implies that training had a positive effect on teachers' attitudes towards inclusive education. The reason for this could be that those with training had capability for handling children with disabilities and therefore have positive attitudes towards them compared to those who were not trained. A previous study by Rajecki (1982) concurs with the above presented findings whereby he argues that attitudes are such an important area to study because they influence so much of our personal lives. To him, attitudes include desires, convictions, feelings, views, opinions, beliefs, hopes, judgments and sentiments. The study of attitudes is thus important because there is a general belief that human behaviour and actions are influenced by attitudes, whereby attitudes are seen as the cause and behaviour as the consequence (Mushoriwa, 1998).

Cava and Madison (1978), suggested that unfavourable teacher attitudes towards accepting handicapped children stem from insecurity and sometimes sentiment, arising from ignorance and inexperience of handicapped children. According to these writers what seems to be important in influencing teachers' attitudes is their knowledge of the implications of handicap and their experience of children with a particular handicap. Many studies have revealed that a handicapped child's position on the teachers' desirability scale had a direct relationship to the teachers' knowledge of that handicap. Among the lowest ranked groups on the desirability scale were children with hearing impairments and visual impairments (Murphy, Dickstein and Dripps, 1960). That teachers need knowledge and understanding of handicap if they are to feel competent to teach a handicapped pupil and to receive him willingly into their classes accord very much with common-sense-reasoning, so also does the idea that experience with a pupil helps teachers feel more confident in having such a child in their class (Lunas, 1986).

Regular teachers in most cases have not received any training on special needs education, and therefore their attitudes towards inclusive education may differ from that of teachers with special needs education training. Table 4.6 shows the regular teachers' attitudes towards inclusive education.

Table 4.6: Regular teachers' attitudes towards inclusive education

\begin{tabular}{llllllllllll}
\multirow{2}{*}{ Statement } & \multicolumn{2}{c}{ SA } & & A & & U & & D & \multicolumn{2}{c}{ SD } \\
\cline { 2 - 9 } & F & $\%$ & F & $\%$ & F & F & $\%$ & F & $\%$ & F \\
\hline
\end{tabular}

1. Regular teachers cannot communicate effectively with the children with disabilities. $\begin{array}{lllllllllll}20 & 26.7 & 30 & 40.0 & 2 & 2.7 & 12 & 16.0 & 11 & 14.7\end{array}$

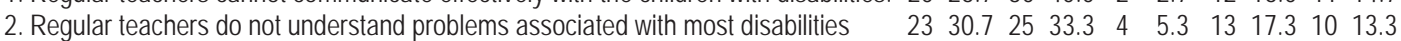

3. Regular teachers cannot make appropriate educational provisions for the children

3. living with disabilities in regular classes

$\begin{array}{llllllllll}11 & 14.7 & 19 & 25.3 & 2 & 2.7 & 21 & 28.0 & 22 & 29.3\end{array}$

4. Regular teachers are well prepared to teach children with disabilities effectively

$\begin{array}{llllllllll}2 & 2.7 & 7 & 9.3 & 2 & 2.7 & 33 & 44.0 & 31 & 41.3\end{array}$

5. Regular teachers are happy to have children with disabilities in their classroom

\begin{tabular}{llllllllll}
2 & 2.7 & 8 & 10.7 & 17 & 22.7 & 22 & 29.3 & 26 & 34.6 \\
\hline
\end{tabular} 
Table 4.6 shows that over 30\% of the regular teachers agreed with the statements that: regular teachers cannot communicate effectively with the children with disabilities and that regular teachers do not understand problems associated with most disabilities. On the other hand, over $30 \%$ of the teachers disagreed with the statements that: regular teachers are happy to have children with disabilities in their classroom and that regular teachers are well prepared to teach children with disabilities effectively. A few of the teachers were undecided.

This shows that regular teachers were not adequately equipped with the required skills to deal with children with disabilities as opposed to those with special needs training. This may be one of the reasons as to why the regular teachers may have a negative attitude towards inclusive education.

With regard to the issue of ideological commitment, the research findings from Schultz (1982) suggest that a belief that handicapped children should be educated in ordinary schools is a significant independent factor in promoting positive attitudes in teachers towards handicapped pupils. Likewise, the provision of special facilities and extra resources for class teachers receiving handicapped children into their classes has been shown to be important by several investigators for example, Schultz (1982). He emphasized that class teachers as well as being given information and advice, should receive additional help such as the services of a classroom or welfare assistance or specialist support teacher. Again, it seems to accord with common-sense reasoning that teachers given extra assistance will feel more favourable to the presence of a handicapped child in the class and more confident in their ability to serve his/her often very time-consuming special needs.

\section{Ways in which Teachers in Schools with Special Units and those without differ in Attitudes Towards Inclusive Education}

The second research objective sought to find out the ways in which teachers with special units and those without differ in attitudes towards inclusive education. In order to establish this, the mean scores obtained by teachers from regular schools with special units on the attitudes toward inclusive education scale were compared with those of teachers from schools without special units. Table 4.7 shows the results

Table 4.7: Differences in attitudes towards inclusive education among teachers in regular schools with special units and those in regular schools

\begin{tabular}{lccc}
\hline & N & Mean & Std. Deviation \\
\hline Regular & 51 & 37.00 & 5.960 \\
Regular with a special unit & 29 & 33.52 & 4.290 \\
Total & $\mathbf{8 0}$ & $\mathbf{3 5 . 7 4}$ & $\mathbf{5 . 6 4 3}$ \\
\hline
\end{tabular}

The information in table 4.7 suggests that teachers from regular schools seemed to have more positive attitudes compared to those from special schools. T-test was used to test the second hypothesis of the study which stated:

Ho2: Teachers in schools with special units and those in schools without special units do not differ in their attitudes towards inclusive education.

To test this hypothesis a t-test was used to determine whether teachers teaching in regular schools with special units and those teaching in regular schools differed significantly in their attitudes toward inclusive education. The result of analysis are shown in table 4.8

Table 4.8: T-test statistics for differences in attitudes towards inclusive education among teachers in regular schools with special units and those in regular schools

\begin{tabular}{lccccc}
\hline & $\mathbf{t}$ & $\mathbf{d f}$ & Sig. (2-tailed) & Mean Difference & Std. Error Difference \\
\hline Equal variances assumed & 2.763 & 78 & $.007^{*}$ & 3.48 & 1.261 \\
Equal variances not assumed & 3.019 & 73.567 & .003 & 3.48 & 1.154 \\
\hline
\end{tabular}

*Significant at $p<0.05$

As shown in table 4.8, the T-test revealed that there were significant differences in attitudes towards inclusive education among teachers in regular schools with special units and those in regular schools at $p<0.05$ level of significance.

This implies that teachers who teach in regular schools with special units may have developed a negative attitude towards children with disabilities due to the work involved in dealing with them compared to those who teach regular 
schools, who seem to be more compassionate to the disabled children. This is because they have stayed with them for long time and hence they are used to their disabilities conditions.

The following study agrees with above presented findings whereby Wilezenski (1992) cited in Booth and Ainscow (1998), conducted a study in Australia on teacher attitudes towards inclusive education. He found that teachers were more positive about students whose programmes focused on social inclusion than those requiring physical changes in their school or classroom.

\section{Effects of Teachers' Acquaintance with Persons living with Disabilities on Attitudes Towards Inclusive Education}

The third objective of the study was to establish the effects of teachers' acquaintance with a person living with a disability on their attitudes toward inclusive education. Having close contact with persons living with disabilities may either positively or negatively influence one's perception of people with disabilities. This may also prove to be true for teachers, since their acquaintance with people living with disabilities may influence their attitudes towards inclusive education. In order to establish this, mean scores obtained by teachers on their acquaintance with persons living with disabilities and teachers acquaintance with persons without disabilities were compared. Table 4.9 shows the mean scores obtained by the teachers on their acquaintance with persons living with disabilities on attitudes towards inclusive education.

Table 4.9: Acquaintance with persons living with disabilities on attitudes towards inclusive education

\begin{tabular}{cccc}
\hline & N & Mean & Std. Deviation \\
\hline Yes & 37 & 36.00 & 5.406 \\
No & 43 & 35.51 & 5.893 \\
Total & $\mathbf{8 0}$ & $\mathbf{3 5 . 7 4}$ & $\mathbf{5 . 6 4 3}$ \\
\hline
\end{tabular}

The information in table 4.9 shows that there is a very slight difference on the attitudes towards inclusive education of teachers who have had an acquaintance with persons living with disabilities and those who have not. T-test was used to test the third hypothesis of the study which stated:

Ho3: Teachers' acquaintance with a person living with a disability does not significantly influence teachers' attitude toward inclusive education

To test this hypothesis, a t-test was used to determine whether teachers' acquaintance with persons living with disabilities and those without disabilities differed significantly in their attitudes toward inclusive education. The results of the analysis are shown in table 4.10 .

Table 4.10: T-test statistics for acquaintance with persons living with disabilities on attitudes towards inclusive education

\begin{tabular}{lccccc}
\hline & $\mathbf{t}$ & $\mathbf{d f}$ & Sig. (2-tailed) & Mean Difference & Std. Error Difference \\
\hline Equal variances assumed & .384 & 78 & $.702^{\star}$ & .49 & 1.272 \\
Equal variances not assumed & .386 & 77.663 & .700 & .49 & 1.264 \\
\hline
\end{tabular}

*Not Significant at $p<0.05$

As shown in table 4.10, the T-test revealed that there were no significant differences in attitudes towards inclusive education among teachers who had an acquaintance with persons living with disabilities and those who had not had an acquaintance at $p<0.05$ level of significance. This implies that acquaintance with people living with disabilities had no effect of teachers' attitudes towards inclusive education.

\section{Gender Differences in Teachers' Attitudes toward Inclusive Education}

The fourth research objective sought to find out the gender differences in teachers' attitudes toward inclusive education. Women by nature are known to be compassionate, so women teachers are expected to have more positive attitudes towards inclusive education compared to the male teachers. In order to answer this question, the mean scores of male and female teachers on the scale measuring attitudes towards inclusive education were compared. 
Table 4.11: Gender differences in teachers' attitudes toward inclusive education

\begin{tabular}{cccc}
\hline & N & Mean & Std. Deviation \\
\hline Male & 35 & 37.40 & 4.473 \\
Female & 45 & 34.44 & 6.148 \\
Total & $\mathbf{8 0}$ & $\mathbf{3 5 . 7 4}$ & $\mathbf{5 . 6 4 3}$ \\
\hline
\end{tabular}

The information in table 4.11 shows that the male teachers seemed to have a more positive attitude than female teachers. This is contrary to popular belief that women are more compassionate than men, therefore female teachers would be expected to be more compassionate towards children with disabilities than male teachers. The female teachers would also be expected to be more positive towards inclusive education compared to male teachers. T-test was used to test the fourth hypothesis of the study which stated:

Ho4: There are no gender differences in teachers' attitudes towards inclusive education.

To test this hypothesis, a t-test was used to determine whether male and female teachers differed significantly in their attitudes toward inclusive education. The results of the analysis are shown in table 4.12.

Table 4.12: T-test statistics for gender differences in teachers' attitudes toward inclusive education

\begin{tabular}{lccccc}
\hline & $\mathbf{t}$ & $\mathbf{d f}$ & Sig. (2-tailed) & Mean Difference & Std. Error Difference \\
\hline Equal variances assumed & 2.392 & 78 & $.019^{\star}$ & 2.96 & 1.235 \\
Equal variances not assumed & 2.488 & 77.699 & .015 & 2.96 & 1.188 \\
\hline Sigl
\end{tabular}

*Significant at $p<0.05$

As shown in table 4.12, the t-test revealed that there were significant gender differences in teachers' attitudes toward inclusive education at $p<0.05$ level of significance. This implies that male teachers had more positive attitudes towards inclusive education compared to their female counterparts. This may be because female teachers are afraid of dealing with children with disabilities due to involvement and commitment they require from them.

\section{Relationship between Disability Type and Teachers' Attitudes toward inclusive Education}

The fifth research objective sought to find out the relationship between disability type and teachers' attitudes towards inclusive education. In order to establish this, the teachers were given a table containing types of disabilities and they were required to state their level of comfort with dealing with the disabilities. Their responses are shown in table 4.13.

Table 4.13: Disability type and teachers' attitudes

\begin{tabular}{lcccc}
\hline \multirow{2}{*}{ Type of disability } & \multicolumn{2}{c}{ Comfortable } & \multicolumn{2}{c}{ Not comfortable } \\
\cline { 2 - 5 } & $\mathbf{F}$ & $\%$ & $\mathbf{F}$ & $\%$ \\
\hline Hearing impairment & 30 & 40.0 & 45 & 60.0 \\
Visual impairment & 27 & 36.0 & 48 & 64.0 \\
Physical impairment & 49 & 65.3 & 26 & 34.7 \\
Mental Impairment & 22 & 29.3 & 53 & 70.7 \\
Learning disability & 53 & 70.7 & 22 & 29.3 \\
Language disability & 36 & 48.0 & 39 & 52.0 \\
Speech disability & 28 & 37.3 & 47 & 62.7 \\
\hline
\end{tabular}

Table 4.13 shows that over $65 \%$ the teachers were most comfortable with dealing with physical impairment and learning disabilities. However, over $60 \%$ of them were uncomfortable with hearing impairment, visual impairment, mental impairment and speech disability. The following were reasons highlighted by teachers that make them uncomfortable when dealing with children with the outlined disabilities.

\subsection{Hearing impairment}

Learners are inattentive and unable to follow or hear teachers' directions/instructions, they fail to respond when called upon by name, they have a tendency to shout un necessarily, they have problems in speaking and understanding sign 
language, some of the pupils have inflamed or running ears and they have poor academic performance which hinders good performance and communication development.

\subsection{Visually impaired}

Learners had difficulties in reading and copying notes as a result they tend to lag behind in learning activities, they have problem of learning concepts that have to be perceived through the sense of sight and shapes, learners have the problems of finding their way within the school and also in the classroom, they are unable to write on straight line, they have problems of identifying objects and visual illustrations e.g. charts, pictures and posters within the class, they lack proper facilities and they lack basic requirement e.g. braile, low vision devices, tactile materials, environmental modification and appropriate teaching /learning strategies.

\subsection{Physically impaired}

These learners have muscular-skeletal, neurological impairment and health impairment e.g. diabetes, heart diseases and sickle-cell anaemia which make them difficult to perform learning activities because they register frequent absenteeism from class to attend clinic and surgical operations.

\subsection{Mental impairment}

These learners thinking ability is less mature than others they have difficulty in generalization, classification, association and abstract thinking, they are unable to focus on relevant stimuli in learning situation and they often require remedial teaching.

\subsection{Learning disability}

These learners manifest significant difficulties in the acquisition and use of listening, speaking, reading, writing, reasoning or mathematical abilities. They need extra time for remedial teaching daily yet the work load is much and may not allow time for Individualized Education Programme (IEP).

\subsection{Language and speech disability}

Learners have unintelligible speech and a lot of grammatical speech, drawing attention of the listeners than what he is saying, have problem in conversation, poor articulation and dysfluences. They also have poor comprehension of materials read that result into poor performance in class.

Generally the two major reasons given by teachers for being uncomfortable when dealing with these disabled pupils were due to lack of adequate skills to guide them in their studies and lack of adequate material. For learners with hearing impairment, the teachers indicated that they did not know sign language and also finger spelling, both of which are essential in the teaching of children with hearing disabilities.

A study done by Peresuh and Ndawi (2001) in Canada argued that countries of the south lack financial, human and material resources to effectively provide educational and related services to learners with visual and hearing impairments. Table 4.14 shows the mean scores obtained by teachers who had encountered persons living with various types of disabilities.

Table 4.14: Differences in attitudes among teachers who had encountered persons living With disability and those who had not encountered

\begin{tabular}{lccc}
\hline \multicolumn{1}{c}{ Disability type } & N & Mean & Std. Deviation \\
\hline Hearing impairment & 8 & 34.00 & 3.665 \\
Visually impaired & 7 & 38.86 & 2.968 \\
Mentally impaired & 7 & 36.14 & 7.358 \\
Physical impaired & 15 & 35.67 & 5.912 \\
None & 43 & 35.51 & 5.893 \\
Total & $\mathbf{8 0}$ & $\mathbf{3 5 . 7 4}$ & $\mathbf{5 . 6 4 3}$ \\
\hline
\end{tabular}


As shown in Table 4.14, there was a very slight difference in the means scores obtained by teachers who had encountered persons with disability and those who had not encountered persons with disabilities. T-test was used to test the fifth hypothesis which stated:

Ho5: Teachers' attitudes toward inclusive education are not significantly influenced by disability types. To test this hypothesis, a t-test was used to determine whether teachers who had encountered persons living with disability and those who had not encountered persons with disability differed significantly in their attitudes toward inclusive education. The results of the analysis are shown in table 4.15.

Table 4.15: T-test statistics for differences in teachers' attitude and disability type

\begin{tabular}{lccccc}
\hline & Sum of Squares & df & Mean Square & F & Sig. \\
\hline Between Groups & 95.696 & 4 & 23.924 & .742 & $.567^{\star}$ \\
Within Groups & 2419.792 & 75 & 32.264 & & \\
Total & $\mathbf{2 5 1 5 . 4 8 8}$ & $\mathbf{7 9}$ & & & \\
\hline
\end{tabular}

*Not significant at $p<0.05$

As shown in Table 4.15, t-test revealed that there were no significant differences in attitudes among teachers who had encountered persons living with disability and those who have not encountered them at $p<0.05$ level of significance. This was an implication that disability type had no influence on teachers' attitude toward inclusive education.

\section{Teachers suggestions on the way to improve teachers' attitudes towards inclusive Education}

Teachers suggested that inclusive education programme in Nyeri-Central can be successful if all teachers are trained on special needs through capacity building workshops, seminars and in-service courses organized at the district level. They also suggested that the government should supply learning materials to reinforce inclusive education programme. The teachers also suggested that modification of the learning environment would be given first priority to make learners with special needs comfortable in school.

The government should set a team of expert to draw a common and friendly syllabus and friendly curriculum to both teachers and learners as it was recommended in the Kenya Education Commission, 1964 (The Ominde Report) and Commission of Inquiry into Education System in Kenya, 1999 (The Koech Report) which recommended the Totally Integrated Quality Education and Training (TIQET) i.e. an inclusive, accommodative, qualitative and life-long education for all.

\section{Conclusion}

Based on the findings of the study as summarized above, it can be concluded that regular teachers with special needs education training had more positive attitudes compared to regular teachers without special needs education training. The study established that training had an effect on teachers' attitudes towards inclusive education. The regular teachers were found to be inadequately equipped with the required skills to deal with children with disabilities as opposed to those with special needs training. The study findings revealed that acquaintance with people living with disabilities had no effect of teachers' attitudes towards inclusive education. It also emerged that the male teachers had a more positive attitude towards inclusive education than female teachers.

\section{References}

Aefsky, F. (1995). Inclusion confusion: A guide to educating students with Exceptional needs. California: Corwin Press Inc. Ainscow, W. (1994). Special needs through school improvement through needs. In Clark et al (Eds.), Towards inclusive. London: Fulton. Ainscow, W. (1999). Understanding inclusive schools. London: Falmer.

Bell, A. W. (1993). Education Research. New York: New York Publishers.

Borg, R., W. and Gall, J. P. (1996). Educational Research. An Introduction (6 $6^{\text {th }}$ Ed), New York: Longman Publishers.

Campbell, J., Gilmore, L. \& Cuskelly, M. (2003). Changing student teachers' attitudes towards disability and inclusion; Journal of Intellectual \& Developmental Disability, 28 (4), 369-379.

Cava, L. \& Madison, O. (1978). The integration of disabled children into the mainstream education: ambitions, theories and practices. Paris: OECD.

Charter of Rights, and Freedoms (1982). Canadian Charter of Rights and Freedoms, http://laws.justice.gc.ca/eng/charter/page-1.html

Dorothy, O. (2003). Handicapped children hiding no more. Retrieved from the East African Standard of Nov. 19, 2003. Retrieved from 
wwww.eastandard.net on Sept. 20, 2006.

Eagley, A.H. \& Chaike, S. (1973). Psychology of attitudes. New York: Harcourt Brace Jovanovich College Publishers.

Frengut, R. (2003) Social Acceptance of Students with Learning Disabilities. Learning Disabilities Association of America, www.LDAAmerica.org.

Gay, L R (1992): Educational Research Competence for Analysis and Application New York Macmillan Publishers Company.

Giocell, L. (1995). Schools for the $21^{\text {st }}$ century inclusive and collaborative paper, presented at the inaugural North-West Special Education Conference: Armidale.

Hall, J. (1992). Segregation by another name. Special Education, April 20-30.

Hegarty, S., Pijl, S.J., Meijer, C.J.W. (1997). Inclusive education - A global agenda. London: Routledge.

Inclusion International (1995). The journey to inclusive schools. Paris: UNESCO.

Inclusion International (1995). The journey to inclusive schools, Paris: UNESCO.

Karugu, G., (2001). The status of inclusive education in Kenya, Kenyatta University, NAIROBI. Unpublished.

Kathuri, N. and Pals, D. (1993), Introduction to Educational Research. Njoro: Egerton University.

Kauffman, J. (1993). The effects of the socio-political environment on developments. Special Education, 17, 3-13.

Kelman H.C. (1962) The induction of action and attitudes change. In S. Coopersmith (Ed), Personality research Copenhagen Munksgaard, pg. 81-110.

Kiess, H. O. and Bloomquist, D. W. (1985). Psychological Research Methods: A Conceptual Approach. Boston: Allyn and Bacon.

Knight, B.A. (1999). Towards inclusion of students with special educational needs in the regular classroom. Support for learning, 14, 13-17.

Luck, J. L. and Rubin, R. S. (1992). Marketing Research. New Delhi: Prentice Hall of India

Lunas, C. (1986). Inclusive Education. A Global Agenda, London: Routledge.

Mugenda, O. and Mugenda, A. (1999). Research Methods: Qualitative and Quantitative Approaches. Nairobi: Acts Press.

Mushoriwa, T.D. (1998). A study of attitudes of African parents in Masuingo District towards educational changes introduced into Zimbabwean secondary schools since independence. Zimbabwe Journal of Educational Research, 10,3, 210-221.

Mwangiri, D. (1989). A study of integration programs for hearing impaired children attending ordinary schools in Kenya. University of Stirling: Unpublished M.Ed. Thesis.

Mwaura, S. (2001). Integration of children with hearing impairments into regular schools. A study of attitudes of primary school teachers. University of Oslo: Unpublished M. Phil.SNE Thesis.

Mwaura, S. (2009). Baseline study on inclusive education/special needs education in Nuba Mountains, Southern Kordofan State, Sudan. Nairobi: Kenya Institute of Special Education.

Olson, J. M. (2003). Special education and general education teacher attitudes toward inclusion; Unpublished MSC Thesis, University of Wisconsin-Stout

Orodho, J. A. (2002). Techniques of Writing Research Proposals and Reports in Education and Social Sciences. Nairobi: Masola Publishers.

Peresuh, M. \& Ndawi, O.P. (2001). Education for all - the challenges for a developing country: The Zimbabwe experience. International Journal of Inclusive Education, 2(3):209-224.

Rajecki, D. W. (1982). Themes and advances. Massachusetts: Snaver Associates Publishers.

Rosenburg M.J. (1953). The experimental investigation of a value theory of attitude structure. Unpublished doctoral dissertation, University of Michigan,

Ryndak, D.L., \& Alper, S. (1996). Curriculum content for students with moderate and severe disabilities in inclusive settings. Needham, Heights, MA: Allyn \& Bacon.

Salamanca Statement (Final Report). Paris: UNESCO.

Savolainen, H. Kokkala, H. \& Alasuutari, H. (1988). Meeting special and diverse educational needs; making inclusive education a reality. Finland: Nilo Maki Institute.

Savolainen, H., Kokkala, H. and Alassuutari, H., (1996). Meeting Special and Diverse Educational Needs: Making Inclusive Education a Reality. Helsinki: Ministry of Foreign Affairs of Finland.

Schultz, L.R. (1982). Educating the special needs students in the regular classroom. Exceptional children, Vo.48, 366-368.

Slec, R. (1995). Education for all. Arguing principles or pretending agreement. Australian Disability Review, 2, 3-19.

Soder, M. (1997). A research perspective on integration. In S. Pijl, C. Meijer, \& S. Hegarty (Eds.), Inclusive education: A globe agenda (pp.14-31). London: Routledge.

Soder, M., (1989). Disability as a social construct. The labelling approach revisited. European.

Stainback, S \& Stainback, W. (1989). Integration of students with mild and moderate handicaps. In D. Lipsky \& A. Gatner (Eds.), Beyond separate education: Quality education forall. Baltimore: Paul H. Brookes.

Stainback, W., \& Stainback, S. (1992). Curriculum considerations in inclusive classroom: Facilitating learning for all students. Baltimore, MD: Paul H. Brookes.

Stangvik, G. (1997). Beyond schooling: integration in a policy perspective. In S.J. Pijl, C.J.W. Meijer \& S. Hegarty (eds.), Inclusive Education. A Global Agenda, p.32-50. London: Routledge.

Stangvik, G. 1997. 'Beyond Schooling: integration in a policy perspective.' In S.J. Pijl, C.J.W. Meijer and S. Hegarty (Eds.). Inclusive Education: A global agenda. London: Routledge: $32-50$.

Tait, K. \& Purdie, N. (2000).Attitudes toward disability: teacher education for inclusive environments in an Australian university. International Journal of Disability, Development and Education, 47(1), 25-38.

UNESCO (1994). World conference on special needs education: Access and equality.

Waruguru, M (2002). Inclusive education Module I - Kenya Institute of Special Education, Nairobi.

Wiersma, W (1995). Research Methods in Education: An Introduction. (2nd Ed) Boston: Allyn Bacon Inc.

Wilcenski, J. L. (1982). Employability Skills for the Special Need Learners. Rockville, MD: Aspen System Corporation. 